\title{
7. Business process outsourcing industry in the Philippines
}

Maddy Thompson

In 2019, the business process outsourcing (BPO) industry was the second largest contributor to the Philippines' economy, providing US\$26 billion to the Philippine economy in 2019 (Rosales 2020) and employing at least I.3 million people in over I,O०० firms, mainly located in urban regions (Reed, Ruehl, and Parkin 2020). BPO workers provide services for overseas corporations including facilitating travel and insurance cover, customer support for technology, and telehealth services. During the COVID-I9 pandemic, the Philippine government exempted the BPO industry from closure during quarantine periods owing to the industry's importance for economic and geopolitical relations. BPO workers were thus exposed to a heightened risk of infection so that overseas economic activities could continue. COVID-I9 did not just disrupt the BPO industry and the overseas corporations it served; it also highlighted and reproduced endemic levels of global inequality and exploitation.

This chapter discusses the growth of the BPO industry in the Philippines with a specific focus on the healthcare information management sector pre-COVID-I9 before examining the various responses that COVID-I9 precipitated. The final section reflects on possibilities for the future of the BPO industry and its workers. Throughout, it is argued that BPO work in the Philippines is a recent example of the ways in which colonial lines of exploitation are redrawn in a digital world.

\section{BPO in the Philippines}

The Philippines' BPO industry began in earnest in the I990s, its growth facilitated by 'overly optimistic' government support (Soriano and Cabañes 2020, p.I). The industry was oriented to the country's former

How to cite this book chapter:

Thompson, Maddy. 2022. 'Business process outsourcing industry in the Philippines'. In: Shin, Hyun Bang; Mckenzie, Murray; and Oh, Do Young (eds) COVID-I9 in Southeast Asia: Insights for a post-pandemic world. London: LSE Press, pp. 86-96. DOI: https://doi.org/I0.3I389/lsepress.cov.g License: CC BY 4.०. 
colonial power, the USA, and also served Europe, Japan, New Zealand, and Australia (BIEN 20I9). Its contribution to the Philippine economy was second only to remittances brought in via migration, and, as of 2020 , the Philippines had the world's largest concentration of call centre workers, although India had the bigger BPO market share (Reed, Ruehl, and Parkin 2020). Where India successfully marketed key cities as hubs of innovation to attract highly skilled BPO activities, the Philippines largely took on back-end processing work ripe for automation. Only around I $5 \%$ of Filipino BPO workers were employed in highly skilled roles before the COVID-I9 pandemic, and Manila's overall ranking of second on the Tholons list of top super cities for digital innovation (see Table 7.I) reflected the size of the BPO industry rather than a culture of digital innovation (Tholons 20I9).

BPO expansion has been connected to the mass emigration of overseas Filipino workers (OFWs) and the Philippines' legacy of colonialism (Soriano and Cabañes 2020; Thompson 2019). As a nation dependent on migration, higher education has tended to reflect Western practices, with most courses instructed in English (Ortiga 20I7). Keeping in touch with migrant family members has also made many Filipinos skilled

Table 7.1. Top super cities for digital innovation according to Tholons (2019)

\begin{tabular}{|l|l|l|}
\hline Rank & City & Country \\
\hline I & Bangalore & India \\
\hline $\mathbf{2}$ & Manila & Philippines \\
\hline 3 & Sao Paulo & Brazil \\
\hline 4 & Mumbai & India \\
\hline 5 & Dublin & Ireland \\
\hline 6 & Toronto & Canada \\
\hline 7 & Delhi & India \\
\hline 8 & Hyderabad & India \\
\hline $\mathbf{9}$ & Singapore & Singapore \\
\hline IO & Buenos Aires & Argentina \\
\hline I I & Krakow & Poland \\
\hline I2 & Cebu City & Philippines \\
\hline$\ldots$ & $\ldots$ & $\ldots$ \\
\hline $\mathbf{9 5}$ & Davao City & Philippines \\
\hline
\end{tabular}


in digital and distanced communication (McKay 2016). In some BPO sectors, the connections between OFWs and BPO workers were more apparent. The healthcare information management sector, for example, emerged in response to heightened demand for healthcare-related insurance processing activities generated by the USA's 20 IO Affordable Care Act (also known as Obamacare) and relied on vast numbers of under- and unemployed nurses whose dreams of migration had 'turned sour' (Ortiga and Macabasag 202I). Global North markets had long encouraged the Philippines to train nurses beyond demand to provide migrant workers (Ortiga and Macabasag 202I), but during the 20IOs, faced with increasing pressures on healthcare systems, rising anti-migration sentiment, and technological advances, outsourcing healthcare via digital platforms became increasingly attractive (Thompson 2019). Incorporating this ready-made, low-cost, highly skilled workforce into the digital health economy allowed profit margins in the global North to increase while restricting the material benefits migration could entail for individuals and their families.

The Philippines' BPO industry has been relatively inclusive. Women have long dominated call centre activities, comprising $53.2 \%$ of the workforce in 2019 (BIEN 20I9), while BPO has been one of the few industries where Filipino LGBTQ+ workers have found safe employment. ${ }^{\mathrm{I}}$ Transgender women in particular entered the industry in the thousands through the early 2000s, mainly in call centre roles (David 20I 5 ). Nonetheless, workers have had variable employment experiences. For permanent employees, BPO roles offer relatively high pay, working benefits (e.g. health insurance), and safe, air-conditioned working environments (Thompson 2019). As the industry grew, however, pay and conditions declined, with an estimated two-fifths of the workforce employed on 'floating'/'no-work-no-pay' status by 2020 (Rabino 2020). Floating workers had their working benefits removed (BIEN 20I7). Such status has been particularly problematic for marginalised groups and those with caring responsibilities, groups that made up the majority of BPO workers in 2020. Additionally, in 2019, an estimated I.5 million Filipinos were digital freelancers, using digital platforms to sell their services. Wood et al. (2019) have found that these online freelancers had few legal labour rights, as rating systems and global competition created a highly competitive and uncertain industry. Despite the lowering of labour standards, the comparatively high pay compared to non-digital employment meant that Filipinos viewed BPO and freelance work as 'good' (Soriano and Cabañes 2020). 


\section{Responding to COVID-19}

The Philippines imposed a nationwide 'enhanced community quarantine' from I6 March 2020 (Ocampo and Yamagishi 2020). Although the nationwide lockdown was later relaxed, urban areas, home to BPO offices, were most affected and experienced stricter and more prolonged periods of quarantine. BPO was one of the few industries exempted from closure, demonstrating its importance to the country's economic and geopolitical interests. However, quarantine restrictions, including the closure of public transport combined with insufficient working-from-home conditions for many employees, meant BPO businesses were unable to maintain normal staffing levels, particularly at the onset of the pandemic. Concurrently, global travel restrictions and national lockdowns elsewhere increased short-term demand for travel and insurance services, while other businesses pulled out (Macaraeg 2020; Oxford Business Group 2020). COVID-I9 thus caused significant disruptions to the industry.

Responses from the foreign businesses impacted varied. Some sought to facilitate homeworking, shipping IT equipment to workers' homes (Sharwood 2020). As the average Manila household had four to five people and a 'poor yet expensive internet connection' (Ocampo and Yamagishi 2020, p.8), homeworking was unsuitable for many. Others provided on-site accommodation to allow workers with quarantining family members or those without caring duties to continue to work (dela Peña 2020). Workers reported that 'accommodation' included sleeping at workstations or sharing hotel rooms without the separation of infected workers from healthy ones (Macaraeg 2020). Though permanent employees were entitled to sick pay, many had their contracts changed to floating status during the pandemic, removing their access to working benefits (Salgado 2020). Workers who were absent to self-isolate or care for family members or who were otherwise physically unable to work thus went unpaid (Macaraeg 2020). As BPO workers were often the primary breadwinners in their household, periods of no pay had the potential to plunge families into poverty.

COVID-I9 both intensified and made more visible the exploitation of BPO workers in the Philippines (see Lawreniuk 2020 for a similar argument in relation to Cambodian garment workers). Those unable to work were made disposable and left without financial security. Those who could work were placed in dangerous settings without proper precautions. The make-up of BPO workers in the Philippines 
placed vulnerable groups - women and LGBT+ groups - at heightened risk of exposure to exploitative conditions. Furthermore, as many $\mathrm{BPO}$ workers were infected and BPO offices were identified as hubs of community transmission nationwide (BIEN 2020), public harassment and discrimination towards BPO workers and returning OFWs occurred (Guadalquiver 2020). BPO workers and migrants, previously perceived as national heroes for their 'service' to the country (Soriano and Cabañes 2020), were transformed into vectors of disease.

The pandemic also made visible the global interconnections that shape BPO. In March 2020, Australian consumers were informed that '[d]ue to increased containment measures announced by the Philippines Government overnight, Telstra's contact centre workforce has been reduced. ... [T] (Sharwood 2020). By both blaming the Philippine government and omitting concern for the workers, companies like Telstra absolved themselves of responsibility for their overseas employees (see also Brydges and Hanlon 2020).

\section{The future of BPO in the Philippines}

Global responses to COVID-I9 included economic protectionism and the tightening of borders. Some foreign companies quickly began reshoring BPO activities, taking advantage of newly unemployed workforces in places with a wider penetration of broadband and home office equipment and where impacts of future lockdowns were more predictable (Reed, Ruehl, and Parkin 2020). The early rapid termination of contracts revealed the exploitation that globalisation had produced, exposing vulnerable workers and their families to increasing precarity. Other businesses were investing further into automation and artificial intelligence, reducing reliance on human-based workforces for low-skilled work (Chen, Marvin, and While 2020). The simultaneous 'throttling' of labour migration caused by COVID-I9 (Abel and GietelBasten 2020) meant that remittances from migrants were disrupted, and many migrants were forced to return to the Philippines (Abrigo et al. 2020). Increased competition from returning migrants likely further exacerbated the erosion of labour standards within the BPO industry.

Longer term, business analysts have predicted that shifts in the acceptability of homeworking and the need for companies to cut costs due to economic downturns could create gains in the outsourcing industry (CBI 2020). These gains are likely to be most prevalent for 
freelance work (Dagooc 2020) and could see the further reduction of tax revenues and workers' rights (Wood et al. 20I9). Sectors that might survive would be those where automation was less of a threat. The healthcare information management (HIM) sector, for example, could see longer-term gains owing to the more skilled nature of the work (Rosales 2020). The HIM sector expanded rapidly over the 2010 s, and before COVID-I9 this growth was expected to continue, as shown in Table 7.2. Revised figures in November 2020 indicated that, while the growth might be less than expected, the industry was still set to grow (IBPAP 2020).

With a world-leading reputation, the Philippines was well-placed to capitalise on the growth in digital health provision that COVID-I9 had precipitated. Indeed, within the first six months of the pandemic, digital health industry insiders estimated there had been the equivalent of five to Io years' expansion in digital health (British Chamber of Commerce 2020), with telehealth operations in particular growing worldwide to maintain both COVID-I9-related and non-COVID-I9-related care activities (Baynham and Hudson 2020). While there have been no guarantees that the transformation to digital health will be permanent, the cost-saving benefits will make it an attractive option for healthcare providers. Furthermore, industry insiders believed that COVID-I9

Table 7.2. Forecasted growth rate of BPO market sectors, 2019-2022

\begin{tabular}{|l|c|c|}
\hline \multirow{2}{*}{ Sector } & \multicolumn{2}{|c|}{$\begin{array}{c}\text { Forecasted percentage change } \\
\text { (prediction intervals) }\end{array}$} \\
\cline { 2 - 3 } & Employees & Revenue \\
\hline $\begin{array}{l}\text { Contact centre and business } \\
\text { processing }\end{array}$ & $2.8-6.7$ & $3 \cdot 3-7.4$ \\
\hline IT & $2.7-6.2$ & $3.2-6.7$ \\
\hline Global in-house centres & $2.7-4 \cdot 7$ & $3.2-5.2$ \\
\hline Healthcare & $6.8-\mathrm{IO} 0.2$ & $7 \cdot 3-\mathrm{IO} .8$ \\
\hline Animation and game development & $6.8-\mathrm{II} \cdot 7$ & $7 \cdot 3-\mathrm{I} 2.3$ \\
\hline Total IT BPO market & $3.0-7.0$ & $3.5-7.5$ \\
\hline $\begin{array}{l}\text { Total IT BPO market (revised } \\
\text { 2020 prediction in light of } \\
\text { COVID-I9) }\end{array}$ & $2.7-5.0$ & $3.2-5 \cdot 5$ \\
\hline
\end{tabular}

Sources: IBPAP (2019; 2020). 
had precipitated a cultural shift, transforming patient and healthcare providers' perceptions as to the acceptability of digital health technologies (British Chamber of Commerce 2020). While this might allow further growth of the HIM sector in the Philippines, there will be an urgent need to question the ethical dimensions of shifting healthcare provision online and overseas.

Tracking the accelerated move to digitally facilitated healthcare, early attention focused on the ability of big data to map COVID-I9 (Brice 2020; Desjardins, Hohl, and Delmelle 2020; Rosenkrantz et al. 202 I), concerns about security and surveillance (Datta 2020), misinformation (Stephens 2020), and the impact of COVID-I9-specific technologies on urban spaces (Chen, Marvin, and While 2020; James et al. 2020; Zeng, Chen, and Lew 2020). Questions of global justice, however, have largely been absent. There is a pressing need to examine how shifts towards digital health in the global North impact the global South. Increases in outsourcing benefit the Philippines but simultaneously exacerbate its vulnerability and dependency on foreign markets. Workers may have access to more stable work, but, with highly uneven healthcare provision in the Philippines, having trained healthcare professionals serving the needs of places with better standards of health raises critical ethical concerns.

\section{Conclusion}

BPO workers in the Philippines were put at risk to avoid 'longer wait times' for consumers in the global North. Looking ahead, it seems likely labour standards in the Philippines' BPO industry will continue to decline, while insufficient infrastructure to facilitate large-scale homeworking could prompt mass withdrawal of FDI, putting the future of the BPO industry and the livelihoods of its workers at risk. While early responses to COVID-I9 described a global 'resurgence of reciprocity' (Springer 2020, p.II2), BPO work shows how COVID-ı9 intensified and made visible enduring forms of global exploitation. Left unchecked, corporate responses to COVID-I9 would further heighten inequalities in an already unequal world.

\section{Note}

I. Unfortunately, no quantitative data exists regarding the numbers of LGBT+ $\mathrm{BPO}$ workers, although qualitative research by Emmanuel David (2OI5) suggests that, in some offices, over half of staff are transgender. 


\section{Acknowledgements}

I would like to thank Deirdre McKay for her helpful comments and encouragement with this work, as well as the ever-helpful and constructive comments from the editors at the LSE, Hyun Bang Shin, Murray Mckenzie, and Do Young Oh.

\section{References}

Abel, Guy J.; and Gietel-Basten, Stuart. (2020). 'International remittance flows and the economic and social consequences of COVID-19'. Environment and Planning A: Economy and Space, vol. 52, no. 8, pp. I480-I482. https:// doi.org/IO.II77/03085I8X2093 I I I I

Abrigo, Michael R.M.; Uy, Jhanna; Haw, Nel Jason; Ulep, Valerie Gilbert T.; and Francisco-Abrigo, Kris. (2020). Projected Disease Transmission, Health System Requirements, and Macro-economic Impacts of the Coronavirus Disease 2019 (COVID-19) in the Philippines. Philippines: Philippine Institute for Development Studies Discussion Paper Series No. 2020-I 5. https://perma.cc/75E6-NJHE [Last accessed I9 May 202I].

Baynham, David; and Hudson, Mary. (2020). 'Rollout of video consultation across general practice'. Technology in the NHS, 26 March. https://perma .cc/X5UZ-UMLC [Last accessed 8 July 2020].

BIEN (BPO Industry Employees Network). (20I7). BPO Workers Protest against Floating Status, Attacks on Job Security in SITEL, 4 July. https:// perma.cc/SC 5 S-7SHL [Last accessed to August 2020].

BIEN. (20I9). Work Flexibilisation and Its Impact on BPO Women Workers in Metro Manila. https://perma.cc/3RFS-NCEU [Last accessed 27 August 2020].

BIEN. (2020). BIEN Sounds Alarm over COVIDI9 Outbreaks in Many BPOs, I3 August. https://perma.cc/2X4R-NPK8 [Last accessed 20 January 202I].

Brice, Jeremy. (2020). 'Charting COVID-I9 futures: Mapping, anticipation, and navigation'. Dialogues in Human Geography, vol. Io, no. 2, pp. 27 I-275. https://doi.org/IO.I I 77/204382062093433 I

British Chamber of Commerce. (2020). The Changing Economic Outlook: Healthcare Industry in South East Asia. https://perma.cc/MP6A-PHVV [Last accessed I I August 2020].

Brydges, Taylor; and Hanlon, Mary. (2020). 'Garment worker rights and the fashion industry's response to COVID-r9'. Dialogues in Human Geography, vol. Io, no. 2, pp. I95-I98. https://doi.org/IO.I I 77/204382062093385 I 
CBI. (2020). Outsourcing Greatly Affected but More Relevant after COVID-I9, 22 April. https://perma.cc/75Q9-8TDS [Last accessed 7 August 2020].

Chen, Bei; Marvin, Simon; and While, Aidan. (2020). 'Containing COVID-I9 in China: AI and the robotic restructuring of future cities'. Dialogues in Human Geography, vol. Io, no. 2, pp. 238-24I. https://doi.org/IO.I I 77 /2043820620934267

Dagooc, Ehda M. (2020). “Gig economy” to rise after ECQ'. The Freeman, I4 April. https://perma.cc/X $7 \mathrm{LF}_{4}$ WQJ [Last accessed I 2 August 2020].

Datta, Ayona. (2020). 'Self(ie)-governance: Technologies of intimate surveillance in India under COVID-I9'. Dialogues in Human Geography, vol. Io, no. 2, pp. 234-237. https://doi.org/IO.I I 77/2043820620929797

David, Emmanuel. (2015). 'Purple-collar labor: Transgender workers and queer value at global call centers in the Philippines'. Gender and Society, vol. 29, no. 2, pp. I69-I94. https://doi.org/IO. I I 77/O89 I 2432 I 4558868

Desjardins, Michael R.; Hohl, Alexander; and Delmelle, Eric M. (2020). 'Rapid surveillance of COVID-I9 in the United States using a prospective space-time scan statistic: Detecting and evaluating emerging clusters'. Applied Geography, vol. I I8, p. I02202. https://doi.org/IO.IOI6/j.apgeog .2020 .102202

Guadalquiver, Nanette. (2020). 'Bacolod folks told not to discriminate vs. BPO workers'. Philippine News Agency, I I August. https://perma.cc/6GQU-PZ $\mathrm{MH}$ [Last accessed 27 August 2020].

IBPAP (IT and Business Process Association of the Philippines). (2019). The Philippine IT-BPM Industry Growth Forecast (2019-2022). https://perma.cc $14 \mathrm{~B}_{5} \mathrm{U}-\mathrm{PGVV}$ [Last accessed 28 April 202I].

IBPAP. (2020). Recalibration of the Philippine IT-BPM Industry Growth Forecasts for 2020-2022. https://perma.cc/4 B 5 U-PGVV [Last accessed 28 April 202I].

James, Philip; Das, Ronnie; Jalosinska, Agata; and Smith, Luke. (2020). 'Smart cities and a data-driven response to COVID-I9'. Dialogues in Human Geography, vol. Io, no. 2, pp. 255-259. https://doi.org/IO.I I77 /20438206209342I I

Lawreniuk, Sabina. (2020). 'Necrocapitalist networks: COVID-I9 and the "dark side" of economic geography'. Dialogues in Human Geography, vol. Io, no. 2, pp. I99-202. https://doi.org/IO.I I 77/2043820620934927

Macaraeg, Pauline. (2020). 'Double whammy: BPO employees get exposed to COVID-ı9, lose income'. Rappler, I9 May. https://perma.cc/A9EA-CBE3 [Last accessed 7 August 2020]. 
McKay, Deirdre. (20I6). An Archipelago of Care: Filipino Migrants and Global Networks. USA: Indiana University Press.

Ocampo, Lanndon; and Yamagishi, Kafferine. (2020). 'Modeling the lockdown relaxation protocols of the Philippine government in response to the COVID-I9 pandemic: An intuitionistic fuzzy DEMATEL analysis'. SocioEconomic Planning Sciences, vol. 72, p. I009 I I. https://doi.org/Io.IoI6/j .seps.2020.I009I I

Ortiga, Yasmin Y. (2017). 'The flexible university: Higher education and the global production of migrant labor'. British Journal of Sociology of Education, vol. 38, no. 4, pp. 485-499. https://doi.org/Io.1080/oI 425692 .20I5.III3857

Ortiga, Yasmin Y.; and Macabasag, Romeo Luis A. (202I). 'Temporality and acquiescent immobility among aspiring nurse migrants in the Philippines'. Journal of Ethnic and Migration Studies, vol. 47, no. 9, pp. I976-1993. https://doi.org/IO.I080/I369I83X.2020.I788380

Oxford Business Group. (2020). What Does the Covid-I9 Outbreak Mean for the Philippines' BPO industry? https://perma.cc/3 3 FH8-C8RX [Last accessed 7 August 2020].

dela Peña, Kurt. (2020). 'Groups urge gov't, companies to prioritize BPO workers' welfare amid pandemic'. Rappler, 24 March. https://perma.cc /SJ9Q-WHHP [Last accessed I I August 2020].

Rabino, Agatha Hazel. (2020). 'Four in Io BPO workers are in floating, no work-no pay status during lockdown'. Manila Today, 6 June. https://perma .cc/YL9D-PNSS [Last accessed ro August 2020].

Reed, John; Ruehl, Mercedes; and Parkin, Benjamin. (2020). 'Coronavirus: Will call centre workers lose their "voice” to AI?' Financial Times, 23 April. https://perma.cc/SB4 C-5ZAU [Last accessed I I August 2020].

Rosales, Elijah Felice. (2020). 'PHL seen bagging more BPO jobs'. BusinessMirror, 8 July. https://perma.cc/LGK8-LY3Z [Last accessed I 2 August 2020].

Rosenkrantz, Leah; Schuurman, Nadine; Bell, Nathaniel; and Amram, Ofer. (202I). 'The need for GIScience in mapping COVID-I9'. Health and Place, vol. 67, p. I02389. https://doi.org/IO.IOI6/j.healthplace.2020.102389

Salgado, Ritchie. (2020). 'BPO workers lament company's lack of compassion amid COVID-ı9’. Bulatlat, I May. https://perma.cc/6D 4A-AEVK [Last accessed I 2 August 2020].

Sharwood, Simon. (2020). 'Philippines sends all workers home, outsourced call centres for Acer and telcos suffer degraded service'. The Register, I 8 March. https://perma.cc/4M2G-XDFG [Last accessed I I August 2020]. 
Soriano, Cheryll Ruth R.; and Cabañes, Jason Vincent A. (2020). 'Entrepreneurial solidarities: Social media collectives and Filipino digital platform workers'. Social Media + Society, April-June 2020, pp. I-I I. https://doi .org/IO.I I 77/2056305 I 20926484

Springer, Simon. (2020). 'Caring geographies: The COVID-r9 interregnum and a return to mutual aid'. Dialogues in Human Geography, vol. Iо, no. 2, pp. I I 2-I I 5. https://doi.org/IO.I I 77/204382062093 I 277

Stephens, Monica. (2020). 'A geospatial infodemic: Mapping Twitter conspiracy theories of COVID-I9'. Dialogues in Human Geography, vol. Iо, no. 2, pp. 276-28I. https://doi.org/IO.I I 77/2043820620935683

Tholons. (2019). Innovation at Scale: Digital Nations and Super Cities. https:// perma.cc/9UMS-LQNK [Last accessed I 2 August 2020].

Thompson, Maddy. (2019). 'Everything changes to stay the same: Persistent global health inequalities amidst new therapeutic opportunities and mobilities for Filipino nurses'. Mobilities, vol. I4, no. I, pp. 38-53. https://doi.org /IO.IO80/I7450IOI.20I8.I 5 I 884 I

Wood, Alex J.; Graham, Mark; Lehdonvirta, Vili; and Hjorth, Isis. (2019). 'Networked but commodified: The (dis)embeddedness of digital labour in the gig economy'. Sociology, vol. 53, no. 5, pp. 93 I-950. https://doi.org /IO.II77/0038038519828906

Zeng, Zhanjing; Chen, Po-Ju; and Lew, Alan A. (2020). 'From high-touch to high-tech: COVID-I9 drives robotics adoption'. Tourism Geographies, vol. 22, no. 3, pp. 724-734. https://doi.org/IO.IO80/I46I6688.2020.I762 I I 8 